\title{
Girişimciliğin Bölgesel Kalkınmaya Etkisi: Şanlıurfa Örneği
}

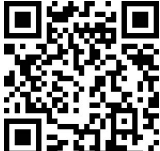

Nihat GÜLTEKİN*

Müslüm SÖNMEZ**

\section{$\ddot{O} z$}

Bu çalışmanın amacı, Şanlıurfa ilindeki girişimcilerin, girişimcilik potansiyeli ve risk alma eğilimlerini ortaya çıkarmaktır. Amaç, girişimciliğ̈in Şanlıurfa ilinin kalkınmasına etkisini araştırmaktır. Araştırmada anket yöntemi kullanılarak Şanlıurfa ilindeki girişimcilerden veriler toplanmış ve SPSS 20 ve Excel 2010 versiyonu kullanılarak verilerin analizi gerçekleştirilmiştir. Risk alma eŭilimi ile girişimcilik potansiyeli arasında yapılan Sperman's Rho sonuçlarına iki değiş̧ken arasından orta kuvvette ve anlamlı bir ilişski var olduğu görülmüsstür. Dahası, başarma ihtiyacı ile risk alma eğilimi ve girişimcilik potansiyeli arasındaki ilişkiyi belirlemeye yönelik yapılan Spearman's Rho-Korelasyon Analizi sonuçlarına göre orta kuvvette pozitif yönlü bir ilişkinin var olduğu saptanmıştır. Yani bir girişimci başarma arzusu içerisinde ise aynı zamanda risk alır ve girişimcilik faaliyetlerinde bulunur. Risk başarma arzusuyla doğru bir orana sahiptir. Ya da bir girişimci, girişimcilik faaliyetlerine başladığı zamanda başarılı olabilmek adına gerekli tüm riskleri alır.

Anahtar Kelimeler: Şanlıurfa, Girişimcilik, Bölgesel Kalkınma.

JEL Kodlart: L26, R13, R58.

\section{Entrepreneurship's Influence in Regional Development: Case of Sanliurfa}

\begin{abstract}
The main aim of this paper is to reveal the entrepreneurial potential and risk-taking tendencies of the entrepreneurs in Sanliurfa province. The aim is to investigate the effect of your entrepreneurship on the development of the province of Sanliurfa. Data were collected from entrepreneurs in Sanliurfa province by using survey method and data analysis was performed using SPSS 20 and Excel 2010 version. According to the results of Spearman's-Rho-Correlation Analysis, which is targeting to determine the relationship between the tendency of risk taking and the potential of entrepreneurship, it is found that there is a significant relationship. Also, given the results of Sperman's Rho, a middle quartile positive correlation is identified between the risk-taking tendency and the entrepreneurial potential. In other words, if an entrepreneur who would like to reach a success does take risks and be in entrepreneurial activities meantime. Risk-taking goes hand-in-hand with the desire to success. Or when an entrepreneur starts their entrepreneurial activities, they take all the necessary risks to be successful.
\end{abstract}

Keywords: Sanliurfa, Entrepreneurship, Regional Development.

JEL Codes: L26, R13, R58.

\footnotetext{
* Doç. Dr., Harran Üniversitesi, İ̇BF, İşletme Bölümü, E-mail: nihat@harran.edu.tr ORCID: http://orcid.org/0000-0001-6692-1628

** Harran Üniversitesi, SBE, Yüksek Lisans Öğrencisi, E-mail: muslumsonmez5@gmail.com
} 


\section{Giriş}

Girişimci üretim faktörlerini bir araya getiren ve kâr elde etmek amaciyla hareket eden kişi olarak bilinse de önemli bir ekonomi motorudur. Bölgesel ve ulusal bakıldığında en orijinal fikirlerle hareket edip bölge ve ülke ekonomisine yönelik faaliyetleri sonucu büyük katkı sağlar. Yani ekonominin itici bir gücüdür. Girişimcinin ekonomiye somut olarak katk1 sağlaması ve sürekli bir yenilik oluşumunu takip ederek hareket etmesi, daha çok ürün ve hizmetin oluşmaya başlamasına, istihdamın yaratılmasına, refahın artmasına en önemlisi de ülke ekonomisinin büyümesine ve dinamik bir yapı kazanmasına katkı sağlar.

Bütün ülkelerin ulusal ve bölgesel kalkınmasında ekonomik, sosyal vb. unsurlar aynı anda gerçekleşmemektedir. Bu ülkelerin gelişmişlik düzeyleriyle paralel sonuçlar doğmaktadır. Gelişmiş ve gelişmekte olan ülkelerde dengeli kalkınmanın ülke geneline yayılması amacı ile çalışmaların yapıldığı, gelişmemiş ülkelerde ise kalkınma ve gelişimin dengesiz olduğu görülmektedir.

Girişimcinin girişim faaliyetlerinde bölgenin kalkınmasında bölge analizini iyi bir şekilde çalışıp, bölgenin en temel ihtiyaçları doğrultusunda hareket etmesi sonucu bölgesel kalkınmanın daha hızlı, kapsamlı, memnuniyet derecesinin yüksek, refah seviyesinin yüksek, bölgenin olumsuzluklarının yenilmesinde ve ülke genelinde bölgeler arası dengesizliğin giderilmesinde büyük etki yaratan bir bölgesel kalkınma politikası kurmasıyla bölgesel gelişimi ve kalkınmayı gerçekleştirebilir. Yani bölgesel kalkınmalarda müteşebbis önemli bir faktör olarak rol oynayabilir.

\section{Teorik Çerçeve}

Bölgesel kalkınma, ülkedeki ekonominin hem bir süreci hem de bir dinamik ürünü olarak tanımlanabilir. Ekonomik kalkınmanın bölgesel kalkınma ürünü olarak değerlendirilmesi; refah düzeyinin, yaşam standartlarının, yatırım hacminin, bölgedeki iş olanaklarının ve çalışma koşullarının daha adil olması ve iyileştirilmesini ifade eder. Bir süreç olarak ise emek piyasalarının geliştirilmesi, altyapının iyileştirilmesi ve sanayinin desteklenmesi olarak algilanmaktadır (Stimson vd., 2006:4).

Bölgesel kalkınma çok boyutlu bir süreçtir. Bunlar bölgenin; sosyal, ekonomik, kültürel, eğitim, sağlık vb. alanlarının dengeli bir şekilde gelişim göstermesine ve bunların sistematik biçimde birbirine bağlı olarak, birbirini tamamlayarak bölgenin kalkınmasına yardımcı olur. Bunların gerçekleştirilmesinde, bölgede bulunan girişimcilerin rolü oldukça fazladır. Girişimciler bölgenin istihdamına katkıda bulunma, işsizliği azaltma, bölgenin rekabet gücünü artırma, endüstriyel yapının iyileştirilmesine olanak sağlama, bölge içinde refah düzeyinin arttırılması, ekonomik büyüme ve kalkınmayı sağlama, yenilikçi fikirlerin bölgeye yayılmasına öncülük etme gibi çalışmaları gerçekleştirmektedir.

Girişimciler bölgenin kalkınmasında, ülke içinde veya dışında yeni pazar arayışlarına girerek, bölge dışına mal ve hizmet satışlarını artırma yoluna gidebilirler. Girişimciler bölgenin sahip olduğu mevcut pazar paylarını genişleterek çeşitli yollarla girişimde bulunurlar. $\mathrm{Bu}$ amaçla geliştirilen girişim sistemleri bölgedeki tüketicilerin satın alma güçlerini yükseltici çabalara girerek, bölgede ekonomik kalkınmayı sağlamayı amaç edinirler, bölgedeki gelir dağılımını daha dengeli hale getirmek ve bölgede ticaretin daha serbestleşmesi amacıyla mevcut engelleri kaldırmak için yoğun bir şekilde mücadele ederler. 
Girişimcilerin bölgesel kalkınma projelerinde hesaplanmış riskleri kabul etme yetenekleri, girişimcileri pilotlara benzetmektedir. Bölgenin yapısını, kültürünü, gelişim seviyesini, bürokrasisini, hesaplanmış risklerini kabul edip bu doğrultuda faaliyette bulunurlar. Girişimci bölgedeki faaliyetleri için riskleri paylaşmak ve azaltmak için mümkün olan her şeyi yapar. Bölgenin sorunlarını önceden görür ve buna göre hareket eder. Başarı için gerekli olanı ve firsatı destekler, riski; tedarikçiler, yerel yönetimler, müşteriler ve ortaklarla paylaşmak için yollar yaratarak girişim işlemlerinin yürütülmesinde kilit rolleri kontrol etmeyi sistematik bir yapı haline getirip, yapının işleyişini kontrollü olarak takip ederler (Pearce, ve Robinson, 2015:388-389).

Girişimci kendi fikir ve görüşleriyle hayata geçirdiği faaliyetlerinde sadece kendi işletmesi çevresinde faaliyet odaklı olarak faaliyetlerini yürütmez aynı zamanda yöresel, bölgesel ve ulusal kalkınmada da önemli bir rol oynar. Girişimcinin kalkınma esaslı faaliyetlerinde oluşturacağ uzun ömürlü olmasını amaçlar. Özellikle geri kalmış bölgelerin sadece ekonomik olarak değil bütün bir kalkınma sürecini yaşamasını amaçlar. Yani girişimci; eğitim, sağlık, turizm, kültür, refah düzeyi, istihdamı artırma, işsizliği azaltma, göçün önlenmesi ve iş gücünün bölgede kalmasını sağlama vb. etmenlerin bölge açısından verimli bir şekilde kalkınmasını amaçlamaktadır (Marangoz vd., 2014:7-15).

Girişimcinin bölgesel ekonomik kalkınma üzerindeki etkisini belirlemeye yönelik yapılan araştırmalar, girişimci şahıs ve firmaların yüksek katma değer, yeni iş olanakları, istihdam oluşturma, işsizliği azaltma ve bölgesel büyümenin oluşturulmasına katkıda bulunduklarını göstermektedir. Girişimcilik ülke genelinde ve yerel bazda ekonomik ölçülerde olumlu etki yapmaktadır. İlaveten girişimcilik kısa ve uzun vadeli bölgesel istihdam üstünde olumlu bir etki yaratmaktadır. Girişimcilik bölgenin sosyal sorununa önemli çözüm olanağı sunduğu gibi bölgenin ekonomik büyümesinin de dinamosu olup tüm bu gelişmelerin baş aktörüdür (Bozkurt, 2011:9-10).

Girişimci, sınırsız bir şekilde adanmışlık, fedakârlık ve kararlılık duygusuna sahiptir. Çok sayıda girişimciye başarılarının sırrını sorduğumuzda kaçınılmaz olarak şundan söz etmektedirler. Girişimcilerin adanmışlık seviyesi, kişisel ekonomik zenginliğini tehlikeye atmaya, işletmenin öncesinden daha düşük bir yaşam biçimine tahammül etmeye ve hatta ailesine ayırdığı zamandan fedakârlık etmeye ne kadar istekli oldukları, içinde bulunduğu olumsuz çevre ile mücadele ruhu ile ölçülebilmektedir (Pearce ve Robinson, 2015:388-389).

Öte yandan daha mikro düzeydeki faktörlere ek olarak, kimi makro etmenlerin de bir ortamdaki girişimcilik düzeyini etkileyebileceği görülmektedir. Bir ülkedeki kişilerin girişimciliğini müspet ya da menfi anlamda etkileyebilecek makro etmenler arasında, o ülkenin ekonomik ve politik sistemi, dini inançları, tarihsel geçmişi ve coğrafyası da görülebilir. Mesela bir ülkedeki politik sistem ve bürokrasinin işleyişi girişimciliği olumlu ya da olumsuz biçimde etkileyebilir. Girişimcinin heves ve kırılganlığını belirleyebilir (Eryılmaz vd., 2015:16).

Genel olarak girişimciyi, kendi sezgi ve tecrübelerinden hareketle, toplumun mevcut ve olası gereksinimleri belirleyerek risk faktörünü göze alıp, geleceğe yönelik kararlar alan birey olarak tanımlayabiliriz. Girişimcilik ülkelerin gelişmişlik seviyelerine göre farklı tanımlar alabilmektedir. Az gelişmiş ülkelerde yapılanmanın, gelişmekte olan ülkelerde kalkınmanın ve gelişmiş ülkelerde ise dinamizmin, refah ve zenginliğin oluşmasında bir etken olarak tanımlanıyor. Çünkü girişimciliğin başarısı sadece bireylerin kendi işletmelerinde sınırlandırılmıyor; aynı zamanda yöresel, bölgesel, ulusal ve uluslararası kalkınmada da etkin rol oynuyor (Kurt vd., 2006:90-100). 
İşletmelerin esas kuruluş gayesi ekonomikliktir. Her işletme, ortaklarının yatırımları karşılığında gelir üretmek maksadıyla kurulur. Günümüzde artan karmaşık süreçte müşteri ihtiyaçlarını anlama ve buna uygun hareket etme, satışlarının devamını sağlama ve satışların yükseltilmesinin esas şartı haline gelmektedir. Buna göre hareket eden işletmeler, hem müşterilerin yani toplumun ihtiyaçlarına, taleplerine cevap verir hem de kendi gelişimlerine katkıda bulunurlar. Sonuçta ekonomik sorumluluk iyi, kaliteli bir ürünü uygun fiyata üreterek müşterileri memnun etmek ve bunun sonucunda işletme ortaklarına kazanç getirmektedir (Marangoz, 2012:65).

Bölgesel kalkınma ve girişimci arasında yakın bir bağın olması bölgenin kalkınmasında çoğunlukla daha olumlu bir etkinin oluşmasına imkân tanır. Çünkü girişimde bulunacak olan girişimci bölgenin nüfusunu, ekonomisini, coğrafyasını ve ihtiyaçlarının neler olduğunu, siyasi sistem ve işleyişini, eğitim seviyesini, doğal kaynakların aktifliğini vb. etmenlerini yakından tanır. O bölgede yaşayan girişimciler tüm bunlar hakkında bilgi sahibi oldukları için girişimleri bölgesel açıdan olumlu bir ilerleme göstermektedir. Bölgenin bir itici gücü olup, aynı zamanda bölgeler arasında dengesizlik oluşmasına engel olmaktadırlar.

Girişimciler bir bölgenin sahip olduğu potansiyeli diğer insanlardan daha erken fark edip bunu firsata çevirmek için girişimde bulunurlar. Firsat ve hedeflere doğru yönelen iyi girişimciler her zaman bölgedeki müşterileri ve müşterilerinin ihtiyaçları hakkında konuşmaktan zevk alırlar. Onları tetikleyen bu haz onların konuşmalarında şu ifadelerde sıkça geçer: $\mathrm{Bu}$ hafta, bu ay ve bu yıl hedeflerinin ne olduğu sorulduğunda hızlı bir şekilde cevap verirler ve sürekli gelişim halinde bulunmaya çaba harcarlar (Pearce ve Robinson, 2015:388389).

Bölgesel kalkınma ve girişimcilik arasında bazen girişimlerin başarısızlıkla sonuçlandığ durumlar da olabiliyor. Bu da bölgede kullanılan kaynakların boşa gitmesine ve israfin oluşmasına neden oluyor. Girişimcinin girişiminde bölge yapısı ve mozaiğine uygun hareket edip bölgesel kalkınmanın dış dünyayla bağlanmaması halinde bölge sosyal ve ekonomik olarak diğer bölgelerin gerisinde kalabilir. Bu durum girişimcinin sadece kalkınmayı o bölgeye has tutması, sonuçta da bölgeler arası eşitsizliğe neden olabiliyor.

Girişimcilik faaliyetlerinin desteklenmesi ve gelişmesinde, bölge düzeyinde yaşanan işsizlik, yetersiz istihdam, eğitimsizlik, refah düzeyi vb. konularda olumlu gelişmeler yaşanmasına imkân sağlayarak bölge kaynaklarının verimli kullanılmasına ve atıl durumdakileri aktifleştirerek daha çok yarar sağlanmasına olanak tanır. Bölge kalkınmasında olumlu etkilerin yaşanması aynı zamanda göç faktöründe azalmaya ve iş gücünün bölgede kalmasına ortam sağlar, bölge kalkınmasının ülke ekonomisi açısından olumlu katkılarının oluşmasına zemin hazırlar. Bütün bunlar bölgede girişimciliğin temel kalkınma motoru olarak görülmesi ve yerel yönetimin girişimcilere sunduğu destekler sayesinde gerçekleşir.

Girişimci bölgesel kalkınmada, kalkınmanın tabana yayılması için bölgedeki halkın düşüncelerini de dikkate alarak faaliyetlerinde halkın katılımını sağlamaktadır. Özellikle girişimci geri kalmış bölgelerde toplumsal ve ekonomik uyumu desteklemekte, ekonomik faaliyetlerin canlanmasına, bölge halkının refah düzeyinin artmasına, işsizliğin azalmasına ve özellikle diğer bölgeler arasındaki dengesizliğin giderilmesi amacıyla bölgesel kalkınmaya katkı sağlar.

Girişimci faaliyetlerinde büyük sermayelerin mecburi kılınmaması ve yatırım ve üretim etkinliğinin belli merkezlerde yoğunlaşmasını önleyerek, bu etkinliğin bölgesel ölçekte de girişim faaliyetlerinin gerçekleşmesine olanak sağlamaktadır. Girişim faaliyetleri bölgesel 
kalkınmada üretici gücün bölgede kalmasını sağlama ve bölge içinde atıl durumda olan kaynakların üretim ve hizmet için kullanılmasına olanak sağlamaktadır.

Bir ülkede girişimcilik faaliyetlerinin desteklenmesi ve bu faaliyetlerin başarılı olmasında hükümetlerin ve yerel yönetimlerin politik kararları etkili olmaktadır. Bölgesel kalkınmada özellikle yerel yönetimlerin kendi bölgelerinde girişim faaliyetlerinde bulunan girişimcilere destek vermesi ile bölgenin o denli hılı, etkili ve uzun süreli bir kalkınma hamlesi içinde olacağı, yapılan çalışmalar neticesinde ortaya konulmuştur. Çünkü yerel yönetim kararları hangi tip girişimcinin faaliyetlerini destekliyorsa bölgenin kaynakları o yöne yönlendiriliyor. $\mathrm{Bu}$ da bölgesel kalkınmada temel olarak daha kolaylaştırıcı, hızlı, dengeli ve etkili olmasını sağlıyor. Aynı zamanda yerel yönetimlerin merkezden aldığı desteklerle yapılan bu girişimlerin makro ekonomide de istikrar, denge sağlamada ve rekabet ortamının oluşmasında etkili olmuştur (Marangoz vd., 2014:7-15).

Girişimcilik faaliyetleri, ülkenin ekonomik büyümesinde ve kalkınmasında büyük bir etken olarak rol almaktadırlar. Çünkü yeni iş ve fikirleri sayesinde birçok yeni ürün ve servis ağları sağlayarak bu rekabetin artmasına olanak sağlar, teknolojik gelişmeleri takip ederek verimliliğin artmasını sağlama, toplum ve bireylerin hayatlarında pozitif bir etki oluşturma vb. katkıları sağlar. Girişimci özgün fikirleriyle, yenilik unsurunu da uygun kullanmasıyla teknolojiden maksimum seviyede yararlanır. Bu sayede üretim kaynaklarından maksimum seviyede yararlanmayı ve kullanmayı sağlar. Girişimciler, yeni yöntem ve fikirlerle üretim kaynaklarının verimliliğini artırıp sosyal ve ekonomik faydayı en yüksek düzeyde sunmayı amaç edinirler. Bundan dolayı girişimciler toplumun ekonomik kalkınması için önemli misyonlar üstlenirler, bunları aşağıdaki gibi sıralayabiliriz (Günal vd., 2014:4-5):

$>$ İşsizlik az gelişmiş ülkelerde büyük bir problem olup ve bunun üstesinden gelmede girişimci kişilerin girişimine destek sağlanıp, girişimci sayısının artmasına olanak sağlamakla, istihdamı yükseltmek en büyük fayda sağlar.

$>$ Toplumda girişimde bulunma eğiliminde olan kişi sayısı ne kadar fazla ise o toplumda ekonomik ve refah düzeyi de o kadar yüksek olur. Yani girişimimci sayısı ve gelişim birbiriyle doğru orantılıdır.

$>$ Girişimci, üretim faktörlerinden biri olan teknolojiyi etkin bir şekilde kullanma ve teknolojinin gelişmesine olanak sağlamada da katkı sağlamalıdır.

$>$ Girişimciler dış pazarlarda kendi ülkelerinin tanıtımına büyük katkı sunarlar.

$>$ Âtıl durumundaki kaynakları aktif hale getirerek onların kullanılmasını sağlarlar.

Girişimci toplumun kalkınmasında ve gelişmesinde öncü bir aktif güçtür. Kendine özgü fikirlerini uygulama olanağına sahip olan girişimciler toplumda sosyal ve ekonomik kalkınmada daha hızlı bir evreye geçilmesine ortam sağlar. Yenilik ve teknolojinin etkin kullanımı sayesinde toplumda oluşmuş olan; işsizlik, yetersiz istihdam, eğitimsizlik, geri kalmışlık vb. durumların hızlı ve etkin şekilde büyük oranda oluşmasına olanak sağlar. Bölgeler arası sosyal ve ekonomik farklılığın ortadan kalkmasına yardımcı olmakla beraber ülkenin gelişim ve kalkınmasında denge figürünün oluşmasına ortam sağlar.

Girişimciliğin ekonomik büyümeyi şu şekilde etkilediğini söyleyebiliriz (Stel, Carree ve Thurik, 2004:5-10):

- Girişimciler orijinal fikirlerle, yeni ürün ve üretim süreçleri ile pazara girerler.

- Girişimcilikte ekonomik etkinlik rekabetin artmasında çok önemlidir. 
- Piyasaya yeni ürünleri sürerek ürünün tutunmasını sağlama, tüketici tercihleri konusunda anlayışı geliştirir ve ürüne erişimini kolaylaştırır.

- Harcadığı çaba ve kazandıkları arasında güçlü bir ilişkinin olması daha etkin çalışmasını ve uzun süre varlığını sürdürmesini sağlar.

Girişimcilik yapısı gereği dinamik bir yapıda olup üretilen mal hizmetler için gerekli pazarların bulunmasında, sunulmasında ve tutundurulmasında önemli bir rol oynamaktadır. Ekonomik kalkınmada pazar etkeni büyük rol oynamaktadır. Çünkü pazar demek ülke ve bölge içinde üretimin sağlanması, istihdamın, işsizliğin, ekonomik ve sosyal kalkınmanın zincirlerinden biridir ve girişimci bunu sağlayarak bu döngünün oluşmasına, dönmesine katkı sağlar.

Türkiye'nin nüfusunun genç ve dinamik bir yapıda olması Türkiye ve bölgesel kalkınma açısından büyük bir fırsat olarak görülebilir. Özellikle de üniversiteden yeni mezun olmuş ve öğrenimi boyunca düşünce yapısını değiştiren, eğitim seviyesini yükselten, okul sonrası iş hayatına ön hazırlıklar yapan genç, yeni mezun olmuş kişiler bölgesel kalkınmada daha çok rol oynayabilir. Geri kalmış bölgelerde genç nüfusun, iş imkânlarının olduğu sanayileşmiş bölgelere göç etmesi bölge açısından önemli bir dinamik kayıp olmuştur. Bu kayıpların önüne geçilmesi için devlet tarafından teşvik edici plân ve projeler sunulması göçün yavaşlamasına etki etmiş, hatta göç bazı bölgelerde durma noktasına kadar gelmiştir. Özellikle doğu ve güneydoğu bölgelerinde genç, dinamik nüfusun fikir ve görüşlerini yaymak, kendini ispatlamak, bildiği işi kendi bölgesinde yapmak gibi fikirleri olan genç insanların daha çok girişimcilik ruhuyla faaliyetlere başlaması, bölge düzeyinde ekonomik, sosyal, kültürel etmenlerin dinamik bir yapıya dönüşmesine ortam hazırlamıştır (Paksoy ve Aydoğdu, 2010:119).

Bölgesel kalkınmanın amacı, bölgenin sahip olduğu potansiyeli ortaya çıkarmak, işlemek, geliştirmek, cazibe haline getirmekle beraber bölgeler arası farklılıkların ortadan kaldırılmasıdır. GAP'ın temel amaçları bu iki amacı da kapsamaktadır. Bölgenin insan gücünü; su kaynaklarını, kültürel tarihini, sermayesini, iş gücü vb. kaynaklarının kullanımını sistematik bir şekilde GAP dâhilinde yürütmeyi amaçlar. GAP bölgesi için en uygun kalkınma dengesinin sağlanmasını amaçlar.

\section{Araştırmanın Metodolojisi}

\subsection{Araştırmanın Amacı}

$\mathrm{Bu}$ çalışmanın amacı; bölgede ekonomik canlılığın arttırılması ve yaygınlaştırılmasında girişimcilerin önemli görevleri olduğunu, bölgesel kalkınma sürecinin hızlandırılması ve bölgesel refah düzeyinin artırılması için, işsizliğin önlenmesinde, toplumsal yapıda değişimci/yenilikçi bir sürecin başlatılmasında girişimciliğin temel bir unsur olduğunu göstermek. Girişimcilik faaliyetleri özellikle; istihdam hacminin genişletilerek işsizliğin önlenmesinde, ekonomik büyümenin hızlandırılmasında ve yeni endüstrilerin doğmasında, refah düzeyinin yükseltilerek geniş bir toplumsal tabana yayılmasında, bölgesel gelişmişlik farklarının ortadan kaldırılmasında ya da azaltılmasında yardımcı olmak gibi ekonomik etkilerinin yanında, girişimciliğin risk üstlenme, yenilikçi ve öncü olma niteliğinden dolayı tüm toplumların değiş̧im ve gelişim süreçlerini izleme, toplumsal yapıda da değişimci/yenilikçi bir sürecin başlatılması, birçok teknolojik buluşun toplumun yararı için yenilikçi ürün ya da hizmetlere dönüştürülmesi ve değer yaratma gibi sosyal alanda da önemli bir etkiye sahiptir. $\mathrm{Bu}$ çalışmanın amacı, bireylerin risk alma ve başarma ihtiyaçlarının girişimcilik potansiyeline etkisinin olup olmadığını belirlemektir. 


\subsection{Araştırmanın Evreni ve Örneklemi}

$\mathrm{Bu}$ çalışmada, GAP'ın lokomotif ili olması nedeniyle Şanlıurfa ilindeki girişimciler, araştırmanın evrenini oluşturmuştur. Şanlıurfa'daki orta ve büyük ölçekli işletmelerden tespit edilen ve ulaşılan 195 işletmeye anket formu gönderilmiştir. Bunların 33 tanesinden geri dönüş alınmamıştır, 12 tanesi de eksik ve kurallara uygun doldurulduğu için değerlendirmeye alınmamıştır. Geriye kalan 150 anket değerlendirmeye alınmıştır. Araştırmanın evreni ve örneklemi ulaşılabilir bireylerin çalışmaya katkısını sağlama amacıyla kolay örneklem yöntemi kullanılmıştır.

\subsection{Araştırmanın Konusu ve Alt Problemler}

$\mathrm{Bu}$ çalışma, bölgeler arası gelişmişlik düzeyinin farklı olduğu Türkiye'de, bu farkın azaltılmasında ya da ortadan kaldırılmasında girişimcilerin nasıl bir rol üstleneceklerini ve kendilerine sunulan devlet destekli finansman ve hibelerle kendi bölgelerinin kalkınmasında nasıl bir katkı sağlayacakları (istihdam, ekonomik gelişmişlik, işsizlik gibi) ve bu durumun kendi bölgelerinde nasıl yönetileceğini gösteren bir çalışmadır.

\subsection{Araştırmanın Önemi}

Bu çalışmada, girişimciliğin Şanlıurfa ilinin kalkınmasında nasıl bir rol oynayacağını ve devlet tarafından girişimcilere sağlanan desteklerin etkili kullanılarak yerel dinamiklerin, ilin kalkınmasında nasıl önemli bir etken olduğu ve yerel ekonomik dinamikler sayesinde Şanlıurfa ilinin ekonomisine ve istihdamına sağlayacağı katkıların neler olacağı gösterilecektir.

\subsection{Veri Toplama Araçları ve Yöntem}

Çalışmanın analizleri IBM SPSS 20 ve Excel 2010 versiyonu kullanılarak hazırlanmıştır. Çalışma, çalışanların kişisel bilgileri ile ilgili 8, katılımcıların başarma ihtiyacını belirlemeye yönelik bilgiler ile ilgili 6 , katılımcıların risk alma eğilimini belirlemeye yönelik bilgiler ile ilgili 6, katılımcıların girişimcilik potansiyelini belirlemeye yönelik bilgiler ile ilgili 12 soru olmak üzere toplamda 32 sorudan oluşmaktadır.

Tüm değişkenlerin frekans (f) ve yüzde (\%) değerleri hesaplanmıştır. Tüm ölçeklere güvenilirlik ve faktör analizleri uygulanmıştır. Ölçeklerin normallik varsayımlarının test edilebilmesi için Kolmogrov Smirnov Testi uygulanmıştır. Ölçekler arasındaki ilişki için Spearman Korelasyon Analizi uygulanmıştır. Sonuçların tamamı tablolar ve yorumları ile birlikte sunulmuştur.

\subsection{Araştırmanın Modeli ve Hipotezleri}

Araştırmanın Modeli ve Hipotezleri Şanlıurfa'da girişimcilere uygulanmıştır. Çalışma girişimcilerin bazı kişilik özelliklerini belirlemeye çalışmasından dolayı betimleyici ve bu kişisel özellikler ile girişimcilerin başarma ihtiyaçları, risk alma eğilimleri ve girişimcilik potansiyelleri arasındaki ilişkinin yönünü ve şiddetini belirlemeye çalışmasından dolayı keşifsel bir çalışma olma özelliğini taşımaktadır. Bu nedenle çalışmamızda tarama modeli kullanılmıştır. Geçmişte ya da hâlen var olan bir durumu olduğu şekilde ortaya koyan araştırma 
yaklaşımı olarak tanımlanan tarama modeli, araştırmalarda araştırmaya konu olan olay ya da olguları oldukları şekliyle açıklamaya çalışmaktadır (Karasar, 1995:77).

Şekil 1: Araştırma Modeli

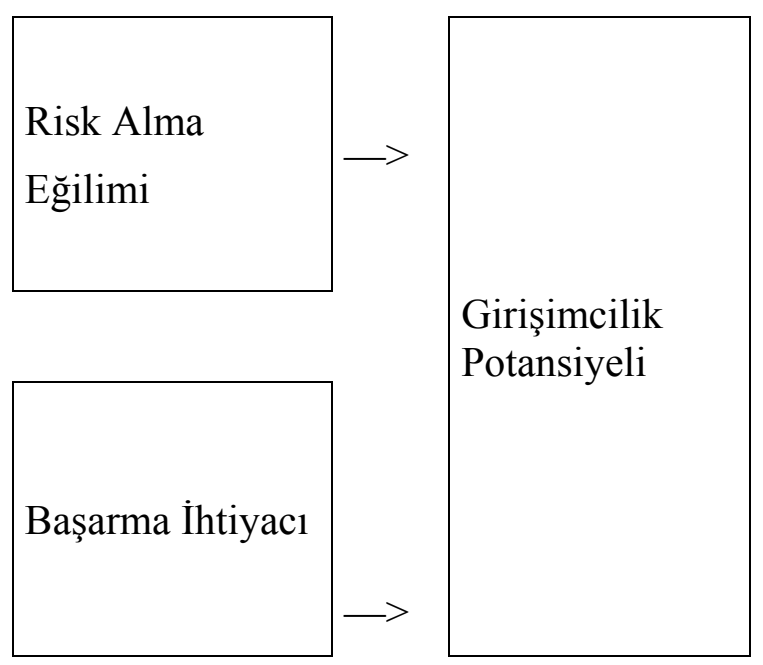

Yukarıda gösterilen kavramsal ifadelere ve literatür taramasına göre araştırmanın hipotezlerini şu şekilde sıralayabiliriz:

\subsection{Araştırmanın Hipotezleri}

H1:Risk alma eğilimi ile girişimcilik potansiyeli arasında anlamlı ve pozitif yönlü bir ilişki vardır.

H2: Başarma ihtiyacı ile girişimcilik potansiyeli arasında anlamlı ve pozitif yönlü bir ilişki vardir.

\subsubsection{Katılımcıların Demografik Özellikleri}

Katılımcıların demografik özelliklerine ait frekans (f) ve yüzde (\%) bulgularına ait sonuçlar Tablo 1'de verilmiştir.

Tablo 1: Demografik Değişkenler

\begin{tabular}{llcc}
\hline Değişkenler & & Frekans (f) & Yüzde (\%) \\
\hline \multirow{3}{*}{ Yaşınız } & 25 Yaş ve Altı & 27 & 18,00 \\
& $26-35$ & 30 & 20,00 \\
& $36-45$ & 54 & 36,00 \\
& 46 Yaş ve Üzeri & 39 & 26,00 \\
& Toplam & 150 & 100,00 \\
\hline \multirow{3}{*}{ Eğitim Durumunuz } & İlköğretim & 17 & 11,30 \\
& Lise & 54 & 36,00 \\
& Üniversite & 66 & 44,00 \\
& Yüksek Lisans & 11 & 7,30 \\
\hline
\end{tabular}




\begin{tabular}{|c|c|c|c|}
\hline & Doktora & 2 & 1,30 \\
\hline & Toplam & 150 & 100,00 \\
\hline \multirow{3}{*}{$\begin{array}{l}\text { Hayatınızın büyük bölümünü } \\
\text { geçirdiğiniz yaşam alanı }\end{array}$} & Kentsel Alan & 99 & 66,00 \\
\hline & Kırsal Alan & 51 & 34,00 \\
\hline & Toplam & 150 & 100,00 \\
\hline \multirow{3}{*}{$\begin{array}{l}\text { Anne veya babanız kendi işine } \\
\text { sahip mi? }\end{array}$} & Evet & 70 & 46,70 \\
\hline & Hayır & 80 & 53,30 \\
\hline & Toplam & 150 & 100,00 \\
\hline \multirow{6}{*}{$\begin{array}{l}\text { Aile bireylerinin toplam sayısı } \\
\text { kaçtır? }\end{array}$} & $1 \mathrm{Kişi}$ & 4 & 2,70 \\
\hline & 2 Kişi & 13 & 8,70 \\
\hline & 3 Kişi & 25 & 16,70 \\
\hline & 4 Kişi & 26 & 17,30 \\
\hline & 5 Kişi ve Üzeri & 82 & 54,70 \\
\hline & Toplam & 150 & 100,00 \\
\hline \multirow{5}{*}{ Yetiştirilme Tarzınız } & Baskıcı & 24 & 16,00 \\
\hline & Serbest & 41 & 27,30 \\
\hline & Kontrollü & 41 & 27,30 \\
\hline & Güvene Dayalı Serbest & 44 & 29,30 \\
\hline & Toplam & 150 & 100,00 \\
\hline \multirow{6}{*}{ Annenizin Eğitim Düzeyi } & Okur-Yazar Değil & 46 & 30,70 \\
\hline & İlköğretim & 67 & 44,70 \\
\hline & Lise & 30 & 20,00 \\
\hline & Ön Lisans & 3 & 2,00 \\
\hline & Üniversite & 4 & 2,70 \\
\hline & Toplam & 150 & 100,00 \\
\hline \multirow{7}{*}{ Babanızın Eğitim Düzeyi } & Okur-Yazar Değil & 12 & 8,00 \\
\hline & İlköğretim & 63 & 42,00 \\
\hline & Lise & 50 & 33,30 \\
\hline & Ön Lisans & 6 & 4,00 \\
\hline & Üniversite & 18 & 12,00 \\
\hline & Lisans Üstü & 1 & 0,70 \\
\hline & Toplam & 150 & 100,00 \\
\hline
\end{tabular}

Tablo 1'de görüldüğü üzere, katılımcıların \%18'inin 25 yaş ve altında, \%20'sinin 26 ile 35 yaş arasında, \%36'sının 36 ile 45 yaş arasında, \%26'sının ise 46 yaş ve üzerinde olduğu görülmektedir. Katılımcıların \%11,30'u ilköğretim mezunu, \%36'sı lise mezunu, \%44'ü üniversite mezunu, \%7,30'u yüksek lisans mezunudur, \%1,30'u ise doktora eğitimini tamamlamıştır. Katılımcıların \%66'sı hayatının büyük bölümünü kentsel alanda, \%34'ü ise kırsal alanda geçirmiştir. Katılımcıların \%46,70'inin anne ya da babasının kendi işine sahip olduğu, \%53,30'unun ise kendi işine sahip olmadığı görülmektedir. Katılımcıların \%16'sı bask1 altında, \%27,30'u serbest olarak, \%27,30'u kontrollü bir şekilde, \%29,30'u ise güvene dayalı bir serbestlik ile yetiştirilmiştir. Katılımcıların anne ve babalarının eğitim durumları da incelenmiştir. Buna göre katılımcıların annelerinin \%30,70'inin, babalarının \%8'inin okur- 
yazar olmadığı görülmüştür. Yine katılımcıların annelerinin \%44,70'inin, babalarının \%42'sinin ilköğretim mezunu olduğu; annelerinin \%20'sinin, babalarının \%33,30'unun lise mezunu olduğu; annelerinin \%2'sinin, babalarının \%4'ünün ön lisans mezunu olduğu; annelerinin \%2,70'inin üniversite, babalarının \%12'sinin üniversite mezunu olduğu görülmüştür. Ek olarak katılımcıların anneleri arasında yüksek lisans eğitimi alan bulunmadığı, babalarının ise yalnızca \%0,70’inin yüksek lisans eğitimi aldığı belirlenmiştir.

\subsubsection{Güvenilirlik Analizi}

Güvenilirlik skalasına ait bulgularda, Cronbach's alfa değeri 0 ile 0,40 arasında ise ölçek güvenilir değil, 0,40 ile 0,60 arasında ise ölçek düşük güvenilirlikte, 0,60 ile 0,80 arasında ise ölçek oldukça güvenilir, 0,80 ile 1,00 arasında ise ölçek yüksek derecede güvenilirdir (Ergün ve Usluel, 2015:20-33).

\subsubsection{Başarma İhtiyacını Belirlemeye Yönelik Bilgilere Ait Güvenilirlik Analizi}

\subsubsection{Güvenilirlik İstatistikleri}

Tablo 2: Güvenilirlik İstatistikleri Gösteren Tablo

\begin{tabular}{cl}
\hline Cronbach's Alfa & n \\
\hline 0,717 & 6 \\
\hline
\end{tabular}

6 öğe ile yapılan güvenilirlik analizinde Cronbach'salfa değeri 0,717 olarak hesaplanmıştır. Elde edilen bu Cronbach's alfa değerine baktığımızda ölçeğin oldukça güvenilir olduğu söylenebilir.

\subsubsection{2 Ölçek İstatistikleri}

Tablo 3: Ölçek İstatistiklerini Gösteren Tablo

\begin{tabular}{cccc}
\hline Ortalama & Varyans & Std. Sapma & n \\
\hline 21,160 & 24,323 & 4,932 & 6 \\
\hline
\end{tabular}

6 değişkenin ortalama \pm std.sapma değeri $21,160 \pm 4,932$, varyansı ise 24,323 olarak hesaplanmıştır. 


\subsubsection{Risk Alma Ĕ̆gilimini Belirlemeye Yönelik Bilgilere Ait Güvenilirlik Analizi}

\subsubsection{Güvenilirlik İstatistikleri}

Tablo 4: Güvenilirlik İstatistikleri Tablosu

\begin{tabular}{cl}
\hline Cronbach's Alfa & n \\
\hline 0,230 & 6 \\
\hline
\end{tabular}

6 öğe ile yapılan güvenilirlik analizinde Cronbach'salfa değeri 0,230 olarak hesaplanmıştır. Elde edilen bu Cronbach's alfa değerine baktığımızda ölçeğin yeterince güvenilir olmadığı söylenebilir.

\subsubsection{2. Ölçek İstatistikleri}

Tablo 5. Ölçek İstatistikleri Tablosu

\begin{tabular}{cccc}
\hline Ortalama & Varyans & Std. Sapma & n \\
\hline 19,240 & 13,056 & 3,613 & 6 \\
\hline
\end{tabular}

6 değişkenin ortalama \pm std.sapma değeri 19,240 $\pm 3,613$, varyansı ise 13,056 olarak hesaplanmıştır.

\subsubsection{Girişimcilik Potansiyelini Belirlemeye Yönelik Bilgilere Ait Güvenilirlik Analizi}

\subsubsection{Güvenilirlik İstatistikleri}

Tablo 6: Güvenilirlik İstatistikleri Tablosu

\begin{tabular}{cl}
\hline Cronbach's Alfa & n \\
\hline 0,808 & 12 \\
\hline
\end{tabular}

12 öğe ile yapılan güvenilirlik analizinde Cronbach'salfa değeri 0,808 olarak hesaplanmıştır. Elde edilen bu Cronbach's alfa değerine baktığımızda ölçeğin yüksek derecede güvenilir olmadığ1 söylenebilir.

\subsubsection{2. Ölçek İstatistikleri}

Tablo 7: Ölçek İstatistikleri Tablosu

\begin{tabular}{cccc}
\hline Ortalama & Varyans & Std. Sapma & n \\
\hline 45,540 & 57,270 & 7,658 & 12 \\
\hline
\end{tabular}


12 değişkenin ortalama \pm std.sapma değeri $45,540 \pm 7,658$, varyansı ise 57,270 olarak hesaplanmıştır.

\subsubsection{3. Ölçekler Arasındaki İlişki}

Katılımcıların başarma ihtiyacını, risk alma eğilimini ve girişimcilik potansiyelini belirlemeye yönelik bilgiler arasındaki ilişkiler Spearman Korelasyon Analizi ile incelenmiş ve sonuçlar Tablo 8'de verilmiştir.

Tablo 8: Başarı İhtiyacı, Risk Alma Eğilimi ve Girişimcilik Potansiyeli Arasındaki İlişkiyi Belirlemeye Yönelik Spearman'srho-Korelasyon Analizi

\begin{tabular}{|c|c|c|c|c|c|}
\hline \multirow{8}{*}{ Spearman'srho } & & & $\mathrm{a}$ & $\mathrm{b}$ & $\mathrm{c}$ \\
\hline & \multirow{3}{*}{ a- Başarma İhtiyacı } & $\mathrm{r}$ & 1 & 0,568 & 0,571 \\
\hline & & $\mathrm{p}$ & & $<0,001$ & $<0,001$ \\
\hline & & $\mathrm{n}$ & & 150 & 150 \\
\hline & \multirow{3}{*}{ b- Risk Alma Eğilimi } & $\mathrm{r}$ & & 1 & 0,550 \\
\hline & & $\mathrm{p}$ & & & $<\mathbf{0 , 0 0 1}$ \\
\hline & & $\mathrm{n}$ & & & 150 \\
\hline & c- Girişimcilik Potansiyeli & $r$ & & & 1 \\
\hline & & $\mathrm{p}$ & & & \\
\hline & & $\mathrm{n}$ & & & \\
\hline
\end{tabular}

Risk alma eğilimi ile girişimcilik potansiyeli arasında yapılan Sperman'srho sonuçlarına göre $(\mathrm{r}=0,55, \mathrm{p}=0,001<0,05)$ iki değişken arasından orta kuvvette ve anlamlı bir ilişki vardır.

Başarma ihtiyacı ile risk alma eğilimi ve girişimcilik potansiyeli arasındaki ilişsiyi belirlemeye yönelik yapılan Spearman'srho- Korelasyon Analizi sonuçlarına göre $(r=571$, $p=0,001<0,05)$ orta kuvvette pozitif yönlü bir ilişki vardır. H2 kabul edilir.

Katılımcıların başarma ihtiyaçları ile risk alma eğilimleri arasındaki ilişkiler için yapılan Spearman analizine göre ölçekler arasında pozitif yönlü ve orta kuvvette, istatistiksel olarak anlamlı bir ilişki vardır $(r=0,568 ; \mathrm{p}<0,05)$.

Katılımcıların başarma ihtiyaçları ile girişimcilik potansiyelleri arasındaki ilişkiler için yapılan Spearman analizine göre ölçekler arasında pozitif yönlü ve orta kuvvette, istatistiksel olarak anlamlı bir ilişki vardır $(\mathrm{r}=0,571 ; \mathrm{p}<0,05)$.

Katılımcıların risk alma eğilimleri ile girişimcilik potansiyelleri arasındaki ilişsiler için yapılan Spearman analizine göre ölçekler arasında pozitif yönlü ve orta kuvvette, istatistiksel olarak anlamlı bir ilişki vardır $(\mathrm{r}=0,550 ; \mathrm{p}<0,05)$.

Çalışmada kullanılan 3 ölçeğin birbirleri ile ilişkileri incelenmiştir. Gerçekleştirilen korelasyon analizleri doğrultusunda $\mathrm{H} 1$ ve $\mathrm{H} 2$ hipotezlerinin kabul edildiği görülmektedir. Buna göre katılımcıların başarma ihtiyaçları, risk alma eğilimleri ve girişimcilik potansiyelleri arasında pozitif yönlü ve istatistiksel olarak anlamlı ilişkiler bulunduğu gözlenmiştir. Yani bir girişimci başarma ihtiyacı içerisinde ise aynı zamanda risk alır ve girişimcilik faaliyetlerinde bulunur. Ya da bir girişimci girişimcilik faaliyetlerine başladığı esnada başarılı olabilmek adına 
gerekli tüm riskleri alır. Çalışmamızda da görüldüğü üzere bu üç olgu birbiri ile anlamlı ilişkiler içerisindedir ve doğru orantılıdırlar.

\section{SONUÇ VE ÖNERILER}

Girişimcinin, girişimcilik faaliyetlerinde yeni bir iş, fikir, yenilik ve düşüncenin ortaya çıkarılmasına, bölge ve ülke kalkınmasına yapacağı katkıdan dolayı girişimcilik faaliyetleri sınırlandırılmamalı, tam tersine desteklenmelidir. Sürekli olarak gelişen ve küreselleşen dünyamızda; sosyal çevre, ekonomik çevre, risk, eğitim durumu, kişisel ve davranışsal özellikler, birey ve toplum gibi etmenler girişimcinin faaliyetlerini etkiler. Bütün bunların sistematik bir şekilde işleyişi, faaliyetlerin olumlu yönde seyir almasını etkiler.

Girişimci kendi çıkarları doğrultusunda en iyiyi sağlamak amacıyla ekonomik koşulları en etkin biçimde kullanıp riski göze alarak; belirsizliğe katlanarak, üretim ve hizmeti yönlendiren veya yöneten, yeni yöntem, tarzlar ve süreçleri geliştiren, yeni pazarlar araştıran ve oluşumunu sağlayan kişiler olarak tanımlanır. Girişimcinin bu tanımından yola çıkarak, içinde bulunduğumuz küresel sürecin koşullarında bölgelerin gelişmesi ve bölgeler arası dengesizliğin azalması, ülkenin kalkınmasında ve gelişmesinde, hızla değişen çağın şartlarına uyum sağlamada girişimciler önemli birer etken olarak kabul edilir.

Girişimcilik potansiyeline sahip bireylerin var olması, ülkenin kalkınmasında ve büyümesinde, büyüme hızının artmasında önemli rol oynamaktadır. Özellikle kendi bölgelerinin kalkınmasında ve gelişmesinde bölgenin sahip olduğu; sosyal, ekonomik, demografik yap1, siyasal, eğitim düzeyi, altyapı vb. etmenlerin risklerini alarak kendi bölgelerinin kalkınmasında büyük rol oynarlar. Kendi bölgelerinin ve diğer bölgeler arasındaki farklılıkların ortadan kalkmasında önemli bir dinamiktirler.

Ülkemizde bölgeler arası dengesizliklerin önemli bir sorun olması, girişimcilik ile kalkınma arasında önemli bir bağ oluşturmaktadır. Bölgelerin sahip olduğu potansiyeli ve kaynakları bakımından farklılıklar oluşturması, bazı bölgelerin gelişim trendini yakalaması ve bazı bölgelerin ise geride kalmasına neden olmaktadır. İşte burada girişimci devreye girerek, geri kalmış bölgelerin tüm sektörleri içine alan, bölgenin sahip olduğu dinamikleri harekete geçirebilen, entegre, sürdürülebilir, bölge insanının ihtiyaç ve beklentilerine cevap verebilen bir bölgesel kalkınma çalışmasını yürütmeyi hedef alarak girişim faaliyetinde bulunur.

Girişimcilik faaliyetleri bir ülkedeki bölgeler arasındaki dengesizliğin oluşmasında, büyük farklılıkların azalmasında önemli bir dinamiktir. Bölgelerin farklı ekonomik gelişmişlik seviyelerinde olmaları bu farklılıkların nedenleridir. Girişimci; istihdam ve zenginlik yaratma, yenilikler yapma, sosyoekonomik ilişkileri geliştirme gibi önemli faaliyetler yürüterek toplumsal faydayı maksimum kılmaya katkıda bulunur. Girişimcilik; rekabet gücü, istihdam yaratma, pazarda varlığın devamını sağlayarak istihdamı sürekli kılma ve nitelikli mal üretimiyle bölgenin ekonomik gelişmeye katkıda bulunma becerisini gerekli kılmaktadır. Bununla birlikte bölgeler arasında rekabet artışı ile verimlilik artışı, birbirini etkileyen bir döngü oluşturmakta; rekabet sebebiyle girişimciler, bölgesel ihtiyaçlara yanıt verecek daha nitelikli mal/hizmet üretimi için işgücünün ve üretimin verimliliğini artırırken, verimlilik artışı, pazarda rekabetin daha fazla hız kazanmasına etki oluşturmaktadır. Bu sayede bölge, daha nitelikli, ucuz ve çeşitli mal/hizmet üretimi ile fayda sağlamakta ve bölgenin ekonomik ve sosyal canlılığı sağlanmaktadır. Tüm bunlar ülkenin kalkınmasında büyük bir rol oynayıp, ülkenin kalkınma politikası amaçlarına ulaşmada daha hızlı bir süreç oluşturmaktadır. 
Girişimci, ülkenin ekonomik büyümesinin ve kalkınmasının sağlanabilirliği açısından oldukça önem arz etmesi, üzerinde durulması gereken önemli bir unsurdur. Ekonomik ve beşerî sermayeye önem vermek gerekmektedir. Girişimciler; belirsizlik ve risk ortamında, bölgesel farklılıkların ortadan kaldırılmasında, yeni ürün/hizmet ve bu ürün veya hizmetlerin üretiminde kullanılan tekniklerin geliştirilmesinde, yeni pazarlar, yeni hammadde kaynakları bularak rekabetin artırılmasında, teknolojiyi ve piyasadaki değişimleri izleyerek değişen koşullara uyum sağlamada, üretilen ürün ve hizmetlerle katma değeri artırmada, istihdamı ve gelir düzeyini artırmada hem bölgelerin hem de ülkenin ekonomik kalkınmasına ve gelişmesine katkıda bulunmaktadırlar. Bu çalışmada; ülkenin ve bölgelerin ekonomik büyüme ve kalkınmasında, bölgeler arasındaki dengesizliğin azaltılmasında girişimcilik faaliyetleri birçok yönden ele alınmıştır.

$\mathrm{Bu}$ çalışmadaki verilere göre girişimcilerin başarma ihtiyaçları, risk alma eğilimleri ve girişimcilik potansiyelleri arasında pozitif yönlü ve istatistiksel olarak anlamlı ilişkiler bulunduğu gözlenmiştir. Girişimcinin girişim aşamasında risk faktörü önemli rol oynamaktadır. Yani bir girişimci başarma ihtiyacı içerisinde ise aynı zamanda risk alır ve girişimcilik faaliyetlerinde bulunur. Risk başarma arzusuyla doğru bir orana sahiptir. Ya da bir girişimci girişimcilik faaliyetlerine başladığı zamanda başarılı olabilmek adına gerekli tüm riskleri alır. Yukarıda da gösterilen olgular bu çalışmamızda görüldüğü üzere ele alınan üç olgu birbiri ile anlamlı ilişkiler içerisindedir ve doğru orantılıdırlar.

$\mathrm{Bu}$ çalışma, Şanlıurfa ilinde faaliyet gösteren girişimciler üzerine yapıldı. İleriki çalışmalarda, farklı illerde, bölgelerde ya da ülkelerde farklı grupların girişimcilik, risk alma ve başarma ihtiyaçlarının başarma ihtiyaçlarının arasındaki ilişkinin belirlenmesi, sonuçların genelleştirilebilmesi açısından önem arz etmektedir. Ayrıca bu çalışma sonucunda elde edilen bulgular ile uygulamacılar ve akademisyenlere rehberlik edeceği düşünülmektedir.

\section{KAYNAKÇA}

Bozkurt, Ö. (2011). Dünyada Ve Türkiye'de Girişimcilik Eğitimi: Başarılı Girişimciler Ve Öğretim Üyelerinden Öneriler. Ankara: Detay Yayıncılık

Ergün, E., \& Usluel, Y.K. (2015). Çevrimiçi Öğrenme Ortamlarında Öğrenci Bağlılık Ölçeği'nin Türkçe Uyarlaması: Geçerlik ve Güvenirlik Çalışması. Eğitim Teknolojisi Kuram ve Uygulama, 5(1), 20-33.

Eryılmaz, M ve Diğerleri (2015). Işsletme Kuram Ve Pratik. Ankara: Ekin Basım Yayın Dağıtım.

Günal, A. ve Diğerleri (2014). "Ekonomik Kalkınmada Girişimciliğin Önemi ve Rolü”, International Conference On Eurasian Economies, 4-5.

Karasar, N. (2008). Bilimsel Araştırma Yöntemi. Ankara: Nobel Yayın Dağıtım.

Kurt, M., Ağca, V. ve Erdoğan, S. (2006). “Afyon Karahisar İli Girişimcilik Performansının Coğrafi Bilgi Sistemleri İle Analizi”, Afyon Kocatepe Üniversitesi İIBF Dergisi, 8(2), 90 100 .

Marangoz, M. (2012). Girişimcilik. İstanbul: İstanbul: Beta Yayıncılık.

Marangoz, M., Kaya, F ve Bakan, H., (2014), "Eğitim Alanı Girişimcilik Niyetini Nasıl Etkilemektedir? Üniversite Öğrencilerine Yönelik Bir Inceleme”, Muğla Sitk1 Koçman 
Üniversitesi İktisadi ve İdari Bilimler Fakültesi Ekonomi ve Yönetim Araştırmaları Dergisi, C:3, S:1, s. 75-95.

Örücü, E. (2013). Modern İşletmecilik. Ankara: Dora Yayınc1lık.

Paksoy, S. ve Aydoğdu, M. (2008), Bölgesel Kalkınmada Girişimciliğin Geliştirilmesi: GAPGiDEM Örnekleri, Girişimcilik ve Kalkınma Dergisi, Y.5, S.1, s.113-134.

Pearce, J ve Robinson, R. (2015). Stratejik Yönetim. Çeviren: Mehmet Barca, Ankara: Nobel Akademi Yayıncılık Eğitim Danışmanlık.

Stel, A ve Diğerleri. (2004). "The Effect of Entrepreneurship on National Economic Growth: An Analysis Using the GEM Database", The First GEM Research Conference.

Stimson, R. J., STOUGH, R. and ROBERTS, B. H. (2006). Regional Economic Development: Analysis and Planning Strategy, Second Edition, Springer, Germany. 


\section{EXTENDED ABSTRACT}

\section{ENTREPRENEURSHIP'S INFLUENCE IN REGIONAL DEVELOPMENT: CASE OF SANLIURFA}

In this study; entrepreneurial activities within the economic growth and development of a country and its territories and in reducing the imbalance between the regions have been dealt with in many ways.

The purpose of this study is to demonstrate that entrepreneurs have an important role in promoting and expanding economic vitality in the region and that entrepreneurship is an essential element in initiating a transformative/innovative process in the social structure in order to speed up the regional development process and increase the level of regional prosperity.

In this study, entrepreneurs in Sanliurfa province formed the universe of the research because of being the locomotive province of GAP (Southeastern Anatolia Project).

Analyzes of the study is made by using IBM SPSS 20 and Excel 2010 version. Frequency (f) and percent (\%) values of all variables are calculated. Reliability and factor analysis is applied to all scales. The Kolmogov Smirnov Test is applied to test the normality assumptions of the scales. Spearman correlation analysis is applied to the relationships between the scales. All results are presented with tables and comment.

According to this study, it is observed that entrepreneurs had positively and statistically significant relationships between achievement needs, risk taking tendencies and entrepreneurial potentials. The risk factor plays an important role in the initiation phase of the entrepreneur. In other words, if an entrepreneur is in need of success, he also takes risks and engages in entrepreneurial activities. Risk has the right ratio to achieve. Or when an entrepreneur starts his entrepreneurial activities, he takes all necessary risks in order to be successful. The phenomena shown above, as seen in our study, are in a meaningful relationship with each other and are directly proportional to each other.

This study was carried out on entrepreneurs operating in Sanliurfa province. The determination of the relationship between the needs of different groups of entrepreneurships, risk taking and achievement in different illusions, regions, countries or countries is of great importance in generalization of the results. It is also thought to guide practitioners and academics with the findings handled at the end of this study. 